$ノ$ ノ

\title{
小型密封容器(クールミル)を用いたイネ細胞の効率的破砕法
}

小泉一愉 ${ }^{1 ）} \cdot$ 今村智弘 1）・高野裕二 ${ }^{2)} \cdot$ 松江登久 ${ }^{2)} \cdot$ 島田浩章 ${ }^{* 1}$

(1) 東京理科大学基礎工学部生物工学科, 千葉県野田市, テ278-8510, ${ }^{2)}$ (有) トッケン, 千葉県柏市, テ 277-0882)

\section{Simple procedure for disruption of rice tissues sealed in a small deep-frozen cell}

Kazuyoshi Koizumi ${ }^{1)}$, Tomohiro Imamura ${ }^{1)}$, Yuji Takano ${ }^{2)}$, Toshihisa Matsue ${ }^{2)}$, Hiroaki Shimada ${ }^{1)}$

(') Department of Biological Science and Technology, Tokyo University of Science, Noda 278-8510, Japan, ${ }^{2)}$ Tokken Inc., Kashiwa 277-0882, Japan)

\section{キーワード：植物組織破砕，自動クールミル，SKミル， 多検体処理}

\section{1. はじめに}

植物細胞から DNA, RNA あるいはタンパク質を効率 よく単離・精製するためには十分に組織を破砕する必要 があるが、イネ等のシリカ化合物が多く含まれる植物の 組織は, ホモジナイザーのよらな単純な器具では細胞壁 の破砕が困難である。これまでに報告されている植物組 織破砕法は，それぞれの植物体固有の性質によりさまざ まな工夫がなされている.これらの組織破砕法の中で, 液 体窒素中に植物組織を投入して超低温条件で破砕する方 法は，広範囲の植物組織に適用可能であり，精製途上で の不純物の混入や RNase やプロテアーゼなどによる分 解を防ぐことができるため, 非常に優れた方法として広 く利用されている（渡辺・杉浦 1989）。しかしながら，液 体窒素中での細胞組織破研法は, 超低温に冷却した乳鉢 と乳棒を用いた手作業に頼るため, 操作中の事故の危険 性が大きく，また多検体の破砕操作を行ならことが困難 であるなどの問題点を抱えている.

動物の骨組織や酵母細胞を効率的に破砕する方法とし てこれまでに密閉容器を用いたセルミル法が開発されて いる（松江 1999）。この方法では，破砕したい細胞組織 をステンレス塊（クラッシャー）と一緒に密閉容器に封 入し，これを手動で激しく振とらすることによって植物 組織が磨砕され，それによって細胞は粉砕される。しか しながら，この方法では，室温で操作を行ならため，細 胞内に含をれる DNase や RNase などの夾雑物の影響は 避けられない. また，この方法をそのままイネ組織の破 砕に準用した場合，植物組織に含まれる様々な繊維状物 質やシリカ化合物による強固な細胞構造のために, 十分

責任編集 : 門脇光一

2002 年 9 月 24 日受領 2003 年 1 月 7 日受理

* Correspondence: shimadah@rs.noda.tus.ac.jp
な破砕効果が得られない.

そこで, 破砕した植物組織から純度の高い DNA, RNA あるいはタンパク質を得るために，これらの分解が少な い液体窒素条件の超低温での細胞破砕を可能にする器具 の開発とこれを用いた新規な細胞破砕法の確立を試み た．ここでは，超低温条件下での植物細胞破砕を可能に したクールミルの開発について報告する.

\section{2. 大容量の細胞破砕を目的とした自動クールミル 装置}

\section{1 自動クールミル装置}

液体窒素冷却下で，安全かつ効率的にイネ緑葉組織を 破碎するための装置の開発と破砕条件の検討を行なっ た。

従来の代表的な方法は，液体窒素で泠却しながらイネ の組織を乳鉢と乳棒を用いて破砕するものである(渡辺・ 杉浦 1989). そこで，この方法の自動化を試みた。 まず, 乳鉢, 乳棒を用いる従来法の機械操作化を検討した. し かし, 操作中の液体窒素飛散の危険性を完全に排除する ことは困難であると考兄られた。また，液体窒素低温条 件下で安定的に運転することができる自動乳鉢の作製は 技術的に困難であった，そのため，自動乳鉢による破砕 操作の自動化はできなかった.

次に，動物の骨組織等の破砕に用いられる密閉容器を 改良し，植物組織破砕用に適用することを検討した。 た機械操作による容器の振とうの連続化および自動化を 試みた。 まず, 植物細胞を破砕するための容器として, 内 径 $30 \mathrm{~mm}$ 高さ $50 \mathrm{~mm}$ の円筒形のステンレス容器とこれ に適合する直径 $30 \mathrm{~mm}$ 高さ $30 \mathrm{~mm}$ の円筒形のステンレ ス塊のクラッシャー（中子）を作製した。液体窒素冷却 による急激な温度变化と超低温での破研操作に耐えるよ らに, 円筒容器には $2 \mathrm{~mm}$ 厚のステンレス鋼を使用した. 容器には, 㸚じ込み式の蓋をセットし, サンプルとクラッ シャ一を投入後，外ネジを締めつけて蓋を固定した（図 1A）。ささらに容器全体を，アタッチメントを介してレシ プロ式の振とう器 (トッケン・TK-SR3) にセットした（図 
1B）。これにより円筒容器に最大振幅約 $10 \mathrm{~cm}$ の連続的 な上下振動を与えることとした。 これを自動クールミル 装置と名付けた.

\section{2 ゲノム DNA の調製}

温室で栽培したイネ緑葉， $1.85 \mathrm{~g}$ をハサミを用いて細 かく切り刻み, 上記のステンレス容器に投入した. 容器 に緑葉と一緒にクラッシャーを入れ，蓋を締めて密封し た. 次に容器全体を液体窒素に沈めて約 5 分間静置し, 容 器全体を液体窒素温度まで冷却した. 冷却後, 容器を取 り出し, レシプロ振とら器に装着し, 最大振動数 (250 rpm) で 10 分間強く振とうした. 振とら後, 容器の 上下を転倒して振とう器に装着し直し, 再び 10 分間振と らした. 合計 20 分間の振とら後, 容器を振とう器より取 り外し, 蓋を開けて破砕された緑葉サンプルを取り出し た.この実験操作後も, 容器は低温が維持されていた. 破 砕された緑葉サンプルは微細粉末として回収された. 回 収したサンプルをビーカーに移し，室温まで温度が上が るのを待って次の操作を行なった. 一方, 対照実験とし て, $1.04 \mathrm{~g}$ のイネ緑葉を細かく切り刻み, 十分に冷却した 乳鉢と乳棒を用いて，液体窒素存下で $20 \sim 30$ 分間かけ て手操作により完全にすりつぶした.

以上の 2 つの破砕処理法で得られた緑葉破砕物から， CTAB 法（Ausubel et al. 1987）によりゲノム DNA の調製 を行なった. その結果, 緑葉 $1 \mathrm{~g}$ あたりのゲノム DNAの 収量はそれぞれ $1.65 \mathrm{mg}$ (自動クールミルによる操作) お よび $1.04 \mathrm{mg}$ (手操作) であった. 図 $2 \mathrm{~A}$ に示すよらにど
ららも純度の高い DNA が得られた。これらの結果から, 手操作によって得られた破砕物を用いて調製したゲノム DNA と，自動クールミル装置を用いて破砕した緑葉破砕 物を用いて調製したゲノム DNA との間で，収量や品質 に顕著な差異は認められなかった。 また，これらのゲノ ム DNA をそれぞれ制限酵素で切断した場合，ともにス ミアな泳動パターンを示した（データ示さず）. 以上の結 果から, 自動クールミル装置を用いた植物細胞破砕法は, ゲノム DNA の抽出に供するサンプル調製法として有効 であることが明らかとなった。

\subsection{RNA の調製}

ゲノム DNA 調製の場合と同様の方法で調製したイネ 緑葉破砕物を用いて, RNA 抽出キット（ナカライテスク， セパゾール RNA I super）を用いた緑葉の全 RNA の調製 を試みた．抽出法はキットに記載されている方法に従っ た. その結果, $1.0 \mathrm{~g}$ の緑葉を自動クールミル装置で調製 した破砕物，手作業で調製した破砕物それぞれを RNA 調製のための出発物質とした場合，それぞれ $302 \mu \mathrm{g}, 366 \mu \mathrm{g}$ の RNA が得られた. ともに高品質な RNA が得られ，こ れらの間には収量, 品質に差異は認められなかった（図 2B).

\section{4 タンパク質の調製}

自動クールミル装置で調製した緑葉破砕物，手作業で 調製した緑葉破砕物それぞれを $2 \mathrm{ml}$ 容量のサンプリン グチューブに入れ，これに $600 \mu \mathrm{l}$ の抽出バッファー $(10 \%$
A
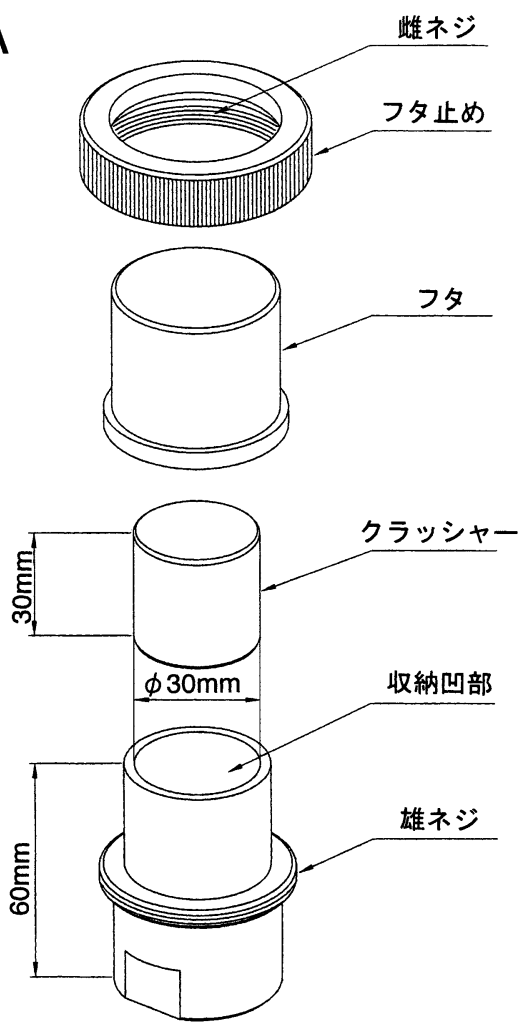

B

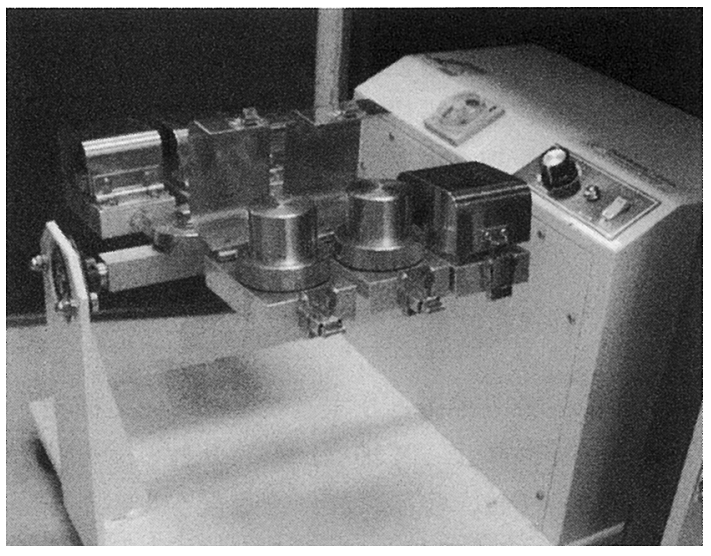

図 1. 自動クールミル装置. $\mathrm{A}$ : クールミルの構造図. 収納凹 部にクラッシャーが格納される. フタは雄ネジと雌ネジ により固定される. B : 自動クールミル装置の外観. 冷 却したクールミルを振とら台にセットし, 上下振とらを 加えることにより, 内部のクラッシャーが上下し, サン プルを破砕する. 
A

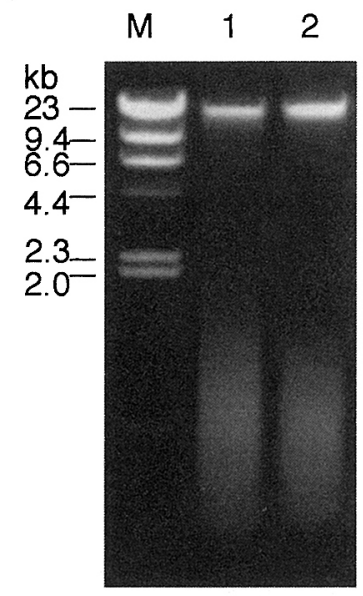

$\mathrm{B}$

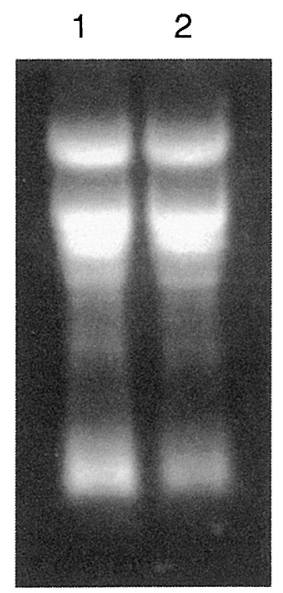

C
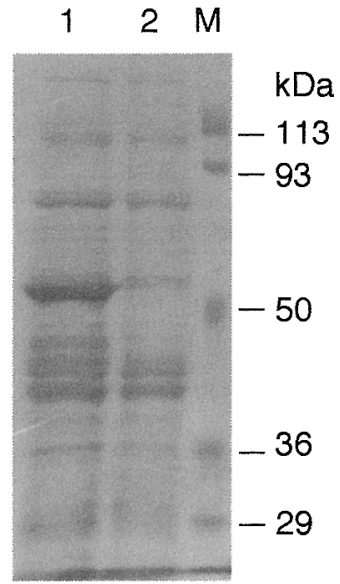

図 2. 自動クールミル装置による抽出. A : ゲノム DNA の抽出結果. それぞれ $0.5 \mu \mathrm{g}$ のゲノム DNAを用いた $1 \%$ アガロースゲル電気 泳動結果を示す. B : 全 RNA の抽出結果. それぞれ $20 \mu \mathrm{g}$ の全 RNAを用いた電気泳動結果を示す。電気泳動には $3 \%$ のホルムア ルデヒドを含む $1 \%$ アガロースゲルを用いた. C : 緑葉のタンパク質粗抽出物を用いた $10 \%$ SDS- ポリアクリルアミドゲル電気泳 動の結果を示す．タンパク質の染色は Coomassie Brilliant Blue R-250を用いた. 図中， M, 1, 2 はそれぞれサイズマーカー，クー ルミルを用いて調製したサンプル，乳鉢と乳棒を用いた手操作によって調製したサンプルであることを示す.

glycerol-100 mM MES (2-morpholinoethanesulfonic acid) 1 mM EDTA (ethylenediamine-N, N, N', N'-tetraacetic acid), pH. 7.0）を加えて激しく混合後, 遠心分離し, その上清 をタンパク質粗抽出液とした. この粗抽出液を $10 \%$ SDSポリアクリルアミド・ゲル電気泳動により分析し, 両者 の泳動パターンを比較した. その結果, それぞれの緑葉 破砕物から得られた粗抽出液に含まれるタンパク質の泳 動パターンに差は認められなかった（図 2C). 収量にも 顕著な差異は認められなかった。 これらのことから，自 動クールミルを用いて破砕する方法は, 従来の乳鉢・乳 棒を用いる方法と遜色ない結果が得られることが明らか になった。

\section{3. 多検体の微量サンプルを処理するための小型 クールミル細胞破砕装置}

小スケールで多検体のサンプル調製のため， クールミ ルの小型化を試みた. 効率的に多数のサンプルを処理す るために, $2 \mathrm{ml}$ 容量のプラスチック製のサンプリング チューブを用いるシステムを検討した. 簡易抽出を可能 にするため, $2 \mathrm{ml}$ サンプリングチューブの形状に合わせ たステンレス製のクラッシャーを作製した.

破砕材料として，ハイグロマイシン耐性遺伝子を導入 した組換え体イネ拈よび非組換え体イネを用いて実験を 行なった. 約 $50 \mathrm{mg}$ の緑葉を切り刻んでサンプリング チューブに投入し，クラッシャーを入れ，蓋をした。 こ れを図 $3 \mathrm{~A}$ に示す形状の 3 本のチューブが装着可能な チューブホルダーに装着して固定した. 次に, このチュー ブホルダーを液体窒素中に沈め, 液体窒素温度まで泠却 した. その後, チューブホルダーを取り出して図 $3 \mathrm{~B}$ に示
すアクリル容器 (アウターケース) にセットし, 手動で 約 5 分間振とうした.

振とら後もチューブホルダーは十分に冷却状態が保持 されていた. 振とらの結果, チューブの中のイネ緑葉は 完全に破砕されており，微細粉末となっていた．そこで 前項と同様に, この操作で得られたイネ緑葉破砕物を用 いて,ゲノム DNAの抽出を試みた. 対照実験として, 約 $50 \mathrm{mg}$ のイネ緑葉を細かく切り刻み, 十分に冷却した乳 鉢と乳棒を用いて, 液体窒素存下で手操作により完全に すりつぶした.

この小型クールミル（SKミルと命名した）を用いて破 砕した植物組織を用いた場合には，振とら時間和よび振 とらの強さにより, 破砕の度合いにばらつきが生じたが, 5 分間の振とらによりほぼ完全に破砕された。一方, 少 量の試料を手操作で破砕した場合には，乳鉢から植物組 織破砕物を回収する際に試料の損失が発生した。しか し, SKミルによる方法と手操作による方法との間で最 終的な収量には顕著な差異は認められなかった。得られ た DNAを用いてハイグロマイシン耐性遺伝子（Roberts et al. 2000）を検出するための PCR を行なった結果, 目的 の遺伝子に対応するバンドが確認された（図 4A）。この 結果から, 得られたゲノム DNA は, サザン分析や PCR に 用いることが可能であることが明らかとなった。

非組換え体イネの未熟種子括よび完熟種子（それぞれ 2 粒) を用いてタンパク質粗抽出液の調製を試みた. それ ぞれより穎を取り除き，SKミルを用いて破砕し，得られ た破砕物からタンパク質粗抽出液の調製を行なった，得 られたタンパク質粗抽出液を用いた SDS- ポリアクリル アミド・ゲル電気泳動では, 主要なタンパク質に対応す る明確なバンドパターンが認められた（図4B）。また，こ 

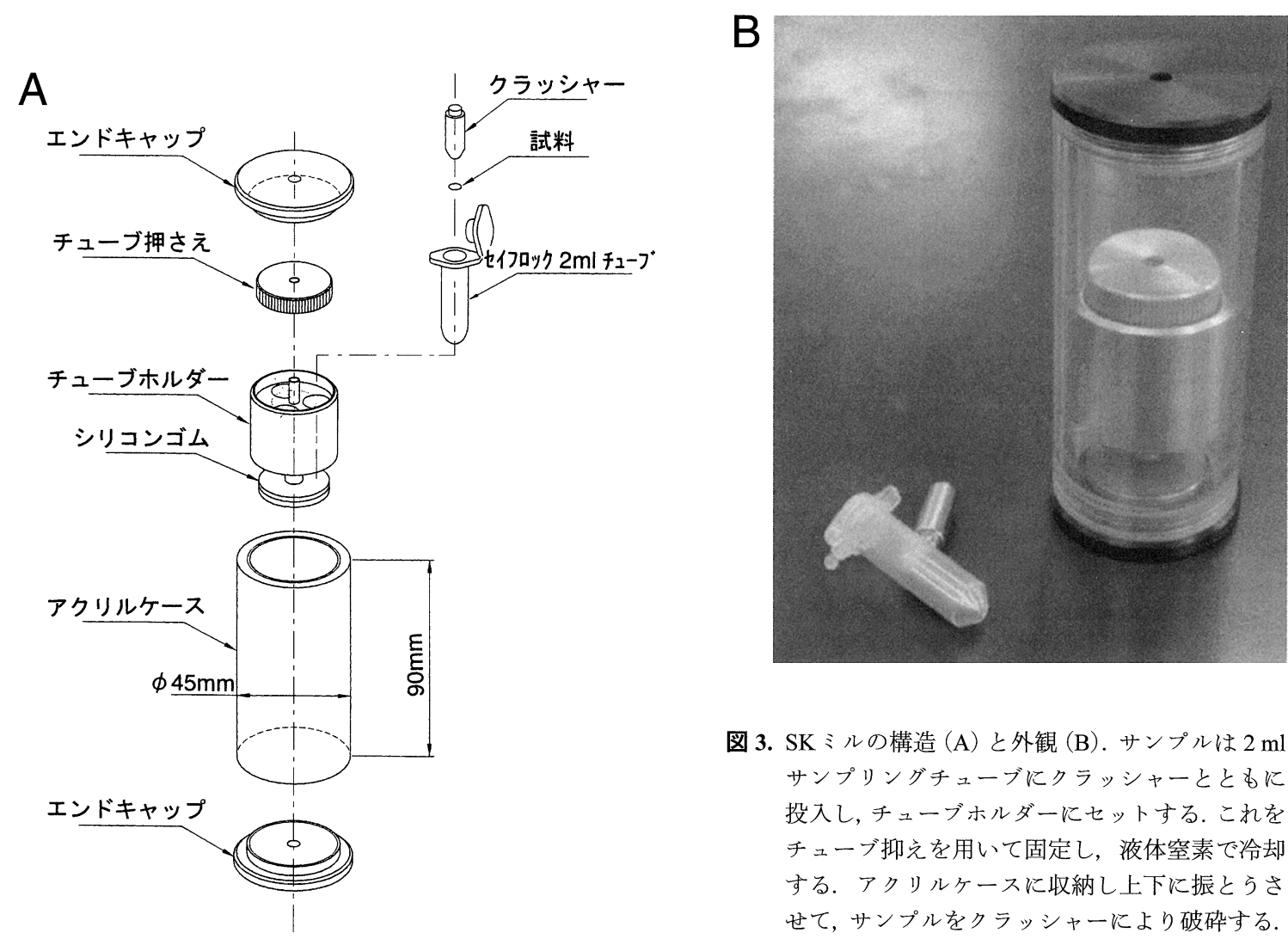

図 3. $\mathrm{SK}$ ミルの構造 (A) と外観 (B).サンプルは $2 \mathrm{ml}$ サンプリングチューブにクラッシャーとともに 投入し，チューブホルダーにセットする.こ机を チューブ抑えを用いて固定し，液体窒素で冷却 する.アクリルケースに収納し上下に振とうさ せて, サンプルをクラッシャーにより破砝する.

A

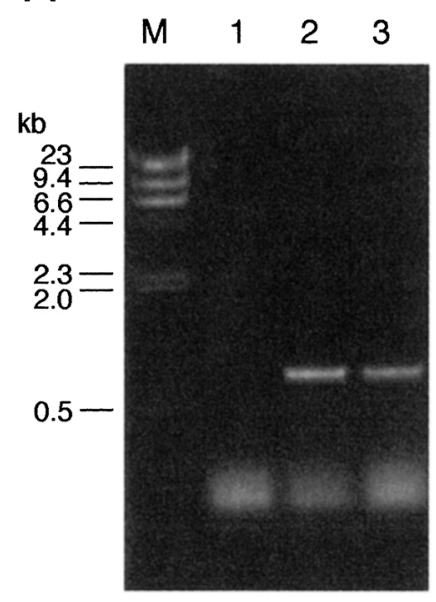

B

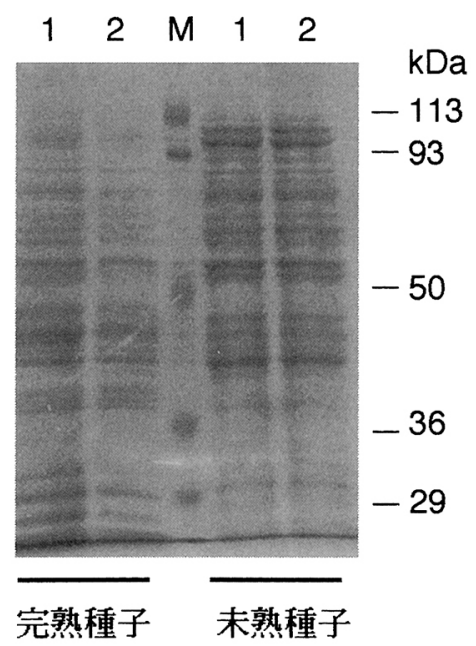

C

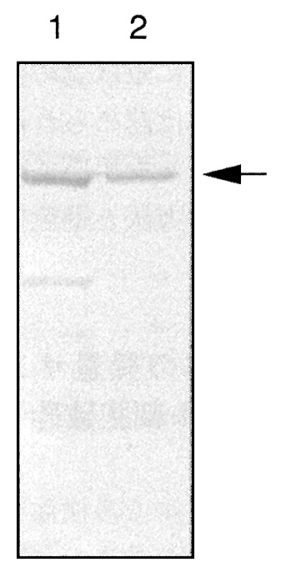

図 4. SKミルを用いた抽出. A : SKミルによって破砕されたイネ緑葉サンプルの PCR の結果. ハイグロマイシン耐性遺伝子を導入し た形質転換体括よび非形質転換体より SKミルを用いてゲノム DNA を抽出し，八イグロマイシン耐性遺伝子に対応するプライ マー（5'-CGGGTAAATACGTGCGCCGATGGT-3' と 5'-TGCTGGGGCGTCGGTTTCCACTAT-3'）（Roberts et al. 2000）を用いて PCR を行なった. 増幅断片は $1 \%$ アガロースゲル電気泳動により分析した. 図中, M はサイズマーカーを, 1 は非組換え体イネ由来の DNA，2,3 はともに組換光体イネ由来の DNA であることを示す. B : 未熟種子のタンパク質粗抽出物を用いた 10\%SDS-ポりアク リルアミドゲル電気泳動の結果を示す．タンパク質の染色は Coomassie Brilliant Blue R-250を用いた. 図中，M，1，2はそれぞれ

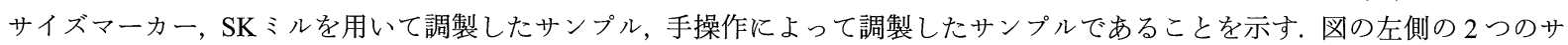
ンプルは完熟種子より, 右側の 2 つサンプルは未熟種子より調製した. C:B のサンプルに対するウェスタン分析の結果を示す. 一次抗体はイネ・ショ糖合成酵素に対する抗ウサギ抗血清を用いた. 図中, 1,2 はそれぞれ SKミルを用いて調製したサンプル, 乳鉢と乳棒を用いた手操作によって調製したサンプルであることを示す。 
のタンパク質粗抽出液を用いてショ糖合成酵素に対する 抗体（Asano et al. 2002）によるウエスタン分析を行なっ たところ，目的とするタンパク質に対応するバンドが確 認された（図 4C)，これらの結果から，SKミルによる組 織破砕は，従来の方法と遜色ない結果が得られることが 明らかになった. この方法は，多検体を同時に処理する ことが可能であるため, 組換光体植物などの遺伝子検定 や特定のタンパク質産生を簡便に検出するために有効で ある。

\section{4. おわりに}

DNA, RNA およびタンパク質を調製するためのイネ細 胞破砕法の効率化を目的として，自動クールミル装置を 開発した. その結果，自動クールミル装置を用いる方法 は, 効率的に純度の高いサンプル調製が可能であること が明らかとなった，この方法は，従来の液体窒素存在下 で乳鉢，乳棒を用いて破砕する方法に置き換えることが 可能であると考えられる. 今回作製した自動クールミル 装置は, 同時に 6 サンプルの処理が可能なものであるが， 装置の改良により,さらに多検体の同時処理も可能とな ると考えられる.

一方，多検体の少量サンプルを処理するために，小型 のクールミルである SKミルを開発した. SK ルルを用い た方法では液体窒素冷却により冷却した $50 \mathrm{mg}$ 程度の少 量の緑葉サンプル，1 粒の未熟種子あるいは完熟種子の 破砕が可能であり, この破砕サンプルから, 純度の高い ゲノム DNA， RNA 执よびタンパク質を調製することが 可能であった.

これらの装置を用いる方法では，ともに液体窒素で冷 却した密封容器を使用することから, 試料の飛散やコン
タミネーションの危険性が回避される。また操作中の液 体窒素による事故に対する安全性も確保されると考兄ら れる，破砕された植物組織からゲノム DNA 等を抽出す る工程は，すでに自動化が可能な抽出キット類が開発さ れて市販されているため，これらと組み合わせることに よって，植物組織からのゲノム DNA 等の抽出操作全体 を自動化することが可能となったものと考えられる。こ のことから，これらの器具を用いる方法は，イネ組織の 破砕法として効果的であることが明らかとなった。

\section{謝 辞}

本研究の一部は日本学術振興会による科学研究費補助 金（No.12556003）の助成により進められた.

\section{引用文献}

Asano, T., N. Kunieda, Y. Omura, H. Ibe, T. Kawasaki, M. Takano, M. Sato, H. Furuhashi, T. Mujin, F. Takaiwa, C. Wu, Y. Tada, T. Satozawa, M. Sakamoto and H. Shimada, H. (2002) Plant Cell 14: 619-628.

Ausubel, F. M., R. Brent, R. E. Kingston, D. D. Moore, J. G. Seidman, J. A. Smith and K. Struhl (eds.) Current protocols in Molecular Biology, (1987), section 2.3.

松江登久（1999）公開特許公報，特開平 11-148890。

Roberts, C., S. Rajagopal, L. M. Smith, T. A. Nguyen, W. Yang, S. Nugrohu, K. S. Ravi, K. Vijayachandra, R. L. Harcourt, L. Dransfield, N. Desamero, I. Slamet, P. Hadjukiewicz, Z. Svab, P. Maliga, J. E. Mayer, P. K. Keese, A. Kilian, and R. A. Jefferson (2000) DDBJ accession no. AF234297.

渡辺格（監修）・杉浦昌弘（編集）（1989）“植物バイオテクノロ ジー実験マニュアル．クローニングとシーケンス“, 農村文 化社, 東京. 252-264. 